\title{
Annexin V Release and Transmembrane Mitochondrial Potential during Storage of Apheresis-Derived Platelets Treated for Pathogen Reduction
}

\author{
Susanne M. Picker Larissa Oustianskaia Volker Schneider Birgit S. Gathof \\ Transfusion Medicine, University of Cologne, Germany
}

\begin{abstract}
Key Words
Pathogen reduction technology - Platelet in vitro function . Endogenous annexin $\mathrm{V}$. Transmembrane mitochondrial potential · INTERCEPT BLOOD SYSTEM · MIRASOL-PRT
\end{abstract}

\section{Summary}

Background: In vitro function of stored platelet (PLT) concentrates was analyzed after applying two different techniques of pathogen reduction technology (PRT) treatment, which could increase cellular injury during processing and storage. Methods: Nine triple-dose PLT apheresis donations were split into 27 single units designated to riboflavin-UVB (M) or psoralen-UVA (I) treatment or remained untreated (C). Throughout 8 days of storage, samples were analyzed for annexin $V$ release, the mitochondrial transmembrane potential $(\Delta \psi)$ and some classical markers of PLT quality $(\mathrm{pH}, \mathrm{LDH}$ release, hypotonic shock response (HSR)). Results: PLT count and LDH release of all units maintained initial ranges. All units exhibited a decrease in $\mathrm{pH}$ and $\mathrm{HSR}$ and an increase in annexin $V$ release and $\Delta \psi$ disruption. Notably, throughout the entire storage period, annexin $\mathrm{V}$ release remained lowest in $\mathrm{M}$ units. Throughout 7 days of storage, $\mathrm{M}$ units remained comparable to $C$ units $(p>0.05)$, whereas inferior values were observed with I units. Here, differences to $\mathrm{C}$ units reached significance by day $1(\mathrm{pH}: \mathrm{p}<0.0001)$, day 5 (annexin $V$ release: $p<0.014$ ), and day 7 (HSR, $\Delta \psi: p$ $\leq 0.003$ ). After PRT treatment, annexin $V$ release and $\Delta \psi$ disruption were significantly $(\mathrm{p}<0.001)$ correlated with $\mathrm{pH}$ and HSR. Conclusion: During storage, all units showed a decrease in HSR and an increase in acidity, annexin $\mathrm{V}$ release and $\Delta \psi$ disruption. While $\mathrm{M}$ units remained comparable to $\mathrm{C}$ units, I units demonstrated significantly inferior values during terminal storage. This could have resulted from differences in PRT treatment or simply be due to differences in storage media and should be analyzed for clinical relevance in future investigations.

\begin{abstract}
Schlüsselwörter
Pathogeninaktivierung - Thrombozytäre In-vitro-Funktion · Endogenes Annexin V . Transmembranes mitochondriales Potential · INTERCEPT BLOOD SYSTEM · MIRASOL-PRT
\end{abstract}

\section{Zusammenfassung}

Hintergrund: Die In-vitro-Funktion gelagerter Thrombozytenkonzentrate wurde nach Anwendung zweier verschiedener Techniken zur Pathogeninaktivierung (PRT) untersucht. Design: Neun Dreifachapheresespenden wurden in 27 Einzeleinheiten geteilt. Eine Einheit wurde mit RiboflavinUVB (M) und die andere mit Psoralen-UVA (I) behandelt. Die dritte blieb unbehandelt $(C)$ und diente als Kontrolle. Während einer Lagerung von 8 Tagen wurden Proben untersucht in Bezug auf die Freisetzung von endogenem Annexin V, das transmembrane mitochondriale Potential $(\Delta \psi)$ sowie die klassischen Marker der Plättchenqualität $(\mathrm{pH}$, LDH-Freisetzung, hypotone Schockreaktion (HSR)). Ergebnisse: In allen Einheiten blieben Plättchenzahl und LDH-Freisetzung im initialen Bereich. Alle Einheiten zeigten einen Abfall des pH, der HSR und des $\Delta \psi$ und einen Anstieg der Freisetzung von endogenem Annexin V. Während der gesamten Lagerungszeit wiesen M-Einheiten diesbezüglich die geringsten Werte auf. Sieben Tage hindurch blieben $\mathrm{M}$ - und $\mathrm{C}$-Einheiten vergleichbar ( $p>0,05)$, während geringere Werte in I-Einheiten beobachtet wurden. Die Unterschiede zu C-Einheiten erreichten hier statistische Signifikanz ab Tag $1(\mathrm{pH}$ : $\mathrm{p}$ $<0,0001$ ), Tag 5 (Annexin-V-Freisetzung: $p<0,014$ ) und Tag 7 (HSR, $\Delta \psi: \mathrm{p} \leq 0,003$ ). Nach der PRT-Behandlung korrelierten $\Delta \psi$ und die Freisetzung von endogenem Annexin $V$ signifikant $(p<0,001)$ mit $\mathrm{pH}$ und HSR. Zusammenfassung: Während der Lagerung aller Einheiten sanken die HSR- und $\Delta \psi$-Werte, während die Azidität und die Annexin-V-Freisetzung zunahmen. Während die $\mathrm{M}$ - und $\mathrm{C}$-Einheiten vergleichbar blieben, zeigten die I-Einheiten im letzten Lagerungsdrittel signifikant niedrigere Werte. Ursächlich hierfür können Unterschiede der PRT-Behandlung oder einfach der Lagerungsmedien sein. Jedoch sollte die klinische Relevanz in künftigen Untersuchungen ermittelt werden.

\begin{tabular}{ll}
\hline KARGER & $($ C 2010 S. Karger GmbH, Freiburg \\
$\begin{array}{l}\text { Fax }+497614520714 \\
\text { Information@Karger.de } \\
\text { www.karger.com }\end{array}$ & $\begin{array}{l}\text { Accessible online at: } \\
\text { www.karger.com/tmh }\end{array}$
\end{tabular}




\section{Introduction}

The psoralen-based INTERCEPT BLOOD SYSTEM (Cerus Corp, Concord, CA, USA) [1-3] and the riboflavin-based MIRASOL-PRT (CaridianBCT Biotechnologies, Lakewood, CO, USA) [4-6] are designed for pathogen reduction (inactivation) of platelet (PLT) concentrates (PCs), which bear the risk of bacterial contamination and growth. Pathogen reduction technologies (PRTs) could affect structural and functional integrity of PLTs during storage. For example, mitochondrial function may be disturbed by targeting mitochondrial nucleic acids. Provided that this would lead to an impaired mitochondria-based oxidative phosphorylation delivering much more biologic energy in form of adenosine triphosphate (ATP) than the anoxidative pathway of the cytosol, direct consequences for energy maintenance and in vitro quality during storage [7] could be expected.

A variety of markers including activation as well as morphologic and metabolic changes are routinely used to monitor PC quality. Rather unusual markers in this field are the detection of disruption of the transmembrane mitochondrial potential $(\Delta \psi)$ to indicate a disturbed mitochondrial function or the release of endogenous annexin $\mathrm{V}$. The latter was shown to be correlated with PLT shape change [8] and may therefore provide a sensitive marker for cellular alteration. Due to a putative binding pocket for the phosphatidylserine (PS) head group [9], studies on endogenous annexin V suggest that PS recognition forms the basis of its physiological function [10]. Blood PLTs were the first cells for which it was demonstrated that changes in the environment, e.g. a rise in receptor activator concentration or a rise in intracellular $\mathrm{Ca}^{2+}$, could enhance PS exposure at the outer membrane leaflet [11,12], which is also promoted by a disturbed mitochondrial function [13]. Apart from induction of phagocytosis [14], PS exposure exhibits procoagulant and proinflammatory activities [15]. This may depict a novel significance for the biological function of annexin $\mathrm{V}$ by shielding PS exposure of the dying cell until being released into the plasma pool. Another clinical significance of annexin $\mathrm{V}$ is the fact that due to its high affinity to negatively charged phospholipid membranes, annexin $\mathrm{V}$ acts as a strong anticoagulant by competing with the binding sites of factors VIIIa and $\mathrm{Va}$ in the tenase and prothrombinase complex assembly [16], probably interfering with the clinical efficacy of PCs.

\section{Material and Methods}

\section{Preparation of $P C$}

Nine triple-dose PLT collections were performed using the Trima Accel apheresis collection device, version 5.1 according to the manufacturer's instructions (CaridianBCT Biotechnologies). All donors gave written informed consent and passed eligibility criteria based on German [17] and European [18] requirements. Collection targets per procedure were $10.0 \times$ $10^{11}$ PLTs in $330 \mathrm{ml}$ of autologous plasma. Collection units were kept un- disturbed for $2 \mathrm{~h}$ at ambient temperature prior to splitting and subsequent processing to allow dissociation of any PLT aggregates. All units were leukodepleted by the process-controlled leukoreduction system. Immediately after splitting, single units were designated to PRT treatment with psoralen-UVA (I) or riboflavin-UVB (M) or remained untreated (C) to serve as controls.

\section{PRT Treatment}

Prior to PRT treatment with the INTERCEPT BLOOD SYSTEM as described previously [19-21], $180 \mathrm{ml}$ of InterSol (Fenwal, Deerfield, IL, USA; composition: $\mathrm{Na}_{3}$ citrate $2 \mathrm{H}_{2} \mathrm{O} 318 \mathrm{mg}$, Na acetate $3 \mathrm{H}_{2} \mathrm{O} 442 \mathrm{mg}$, $\mathrm{NaH}_{2} \mathrm{PO}_{4} 2 \mathrm{H}_{2} \mathrm{O} 105 \mathrm{mg}, \mathrm{NaH}_{2} \mathrm{PO}_{4} 305 \mathrm{mg}, \mathrm{NaCl} 452 \mathrm{mg}$ ) was added to I units. $\mathrm{M}$ units received $150 \mathrm{ml}$ of SSP+ (MacoPharma, Langen, Germany; composition: $\mathrm{Na}_{3}$ citrate $2 \mathrm{H}_{2} \mathrm{O} 3.18 \mathrm{~g}, \mathrm{Na}$ acetate $3 \mathrm{H}_{2} \mathrm{O} 4.42 \mathrm{~g}, \mathrm{NaH}_{2} \mathrm{PO}_{4}$ $2 \mathrm{H}_{2} \mathrm{O} 1.05 \mathrm{~g}, \mathrm{NaH}_{2} \mathrm{PO}_{4} 3.05 \mathrm{~g}, \mathrm{NaCl} 4.05 \mathrm{~g}, \mathrm{KCl} 0.37 \mathrm{~g}, \mathrm{MgCl}_{2} 6 \mathrm{H}_{2} \mathrm{O} 0.30$ g) after PRT treatment with MIRASOL-PRT according to the manufacturers' instructions [22-24]. Untreated C units were resuspended in 150 $\mathrm{ml}$ of InterSol plus $30 \mathrm{ml}$ saline to compensate for the addition of photosensitizers. The overall plasma ratio was $35-40 \%$.

\section{Sampling and Storage of PCs}

Prior to splitting and PRT treatment, a sample volume of $4 \mathrm{ml}$ was taken aseptically from the whole collection unit and diluted with $6 \mathrm{ml}$ of saline to compensate for the addition of PLT additive solution (PAS). Thereafter, the collection unit was split equally into 3 single units (I, M, C). All 27 single units were stored for 8 days in PL2410 plastic bags at $22 \pm 2{ }^{\circ} \mathrm{C}$ on an horizontal flatbed agitator (Helmer Laboratories, Noblesville, IN, USA) running at 50-60 $\times \mathrm{min}^{-1}$. Additional samples were taken aseptically on storage days $1,5,7$, and 8 .

\section{Analysis of Cell Count, LDH Release, pH, Hypotonic Shock Response} (HSR) and Bacterial Contamination

Evaluation of PLT count, contamination with red and white blood cells via flow cytometry, LDH release, HSR, and bacterial contamination with the Bactec ${ }^{\circledast}$ culturing system (Becton Dickinson, San Jose, CA, USA) were performed as described previously $[25,26]$. The $\mathrm{pH}$ value was analyzed at $37{ }^{\circ} \mathrm{C}$ on an automated blood gas analyzer (Rapidlab 1260, Siemens Medical Solutions Diagnostics mbH, Fernwald, Germany) and corrected to $22^{\circ} \mathrm{C}$

\section{Analysis of Released Annexin $V$}

Annexin $V$ release was analyzed by ELISA technology (ELISA Annexin V, Haemochrom Diagnostica GmbH, Essen, Germany) from PLT-poor plasma (PPP) obtained immediately after sampling by centrifugation at $2,000 \times g$ for $30 \mathrm{~min}$ and frozen at $-70{ }^{\circ} \mathrm{C}$ until being analyzed. In brief, immediately after thawing, PPP was incubated in a microwell precoated with rabbit polyclonal antibodies ( $\mathrm{F}\left(\mathrm{ab} \mathrm{b}^{\prime}\right) 2$ fragments) specific for human annexin V. Peroxidase-labelled polyclonal anti-annexin V antibody and tetramethylbenzidine/ $\mathrm{H}_{2} \mathrm{O}_{2}$ were used as conjugate and substrate, respectively. The reaction was stopped after 5 min with $0.45 \mathrm{~mol} / 1$ sulphuric acid, and the absorbance was read at $450 \mathrm{~nm}$.

\section{Assessment of the $\Delta \psi$}

Upon accumulation in mitochondria with polarized membranes, the dye JC-1 (J-aggregate-forming lipophilic cationic fluorochrome 5,5',6,6'-tetrachloro-1,1'3,3'-tetraethylbenzimidazolylcarbocyanine iodide) shows red fluorescence emission (aggregate state). When staying in the cytosol (because of depolarized mitochondrial membranes), JC-1 changes the fluorescent emission spectrum from red to green (monomer state). To evaluate the $\Delta \psi$, a commercially available JC-1 assay (Mitoscreen $\mathrm{BD}^{\mathrm{TM}}$, Becton Dickinson) was used and analyzed on a FACScan (Becton Dickinson) according to the manufacturer's instructions. Data were analyzed with the software CELLQuest Pro (Becton Dickinson) and expressed as percentage of cells with polarized/depolarized mitochondrial potential. 

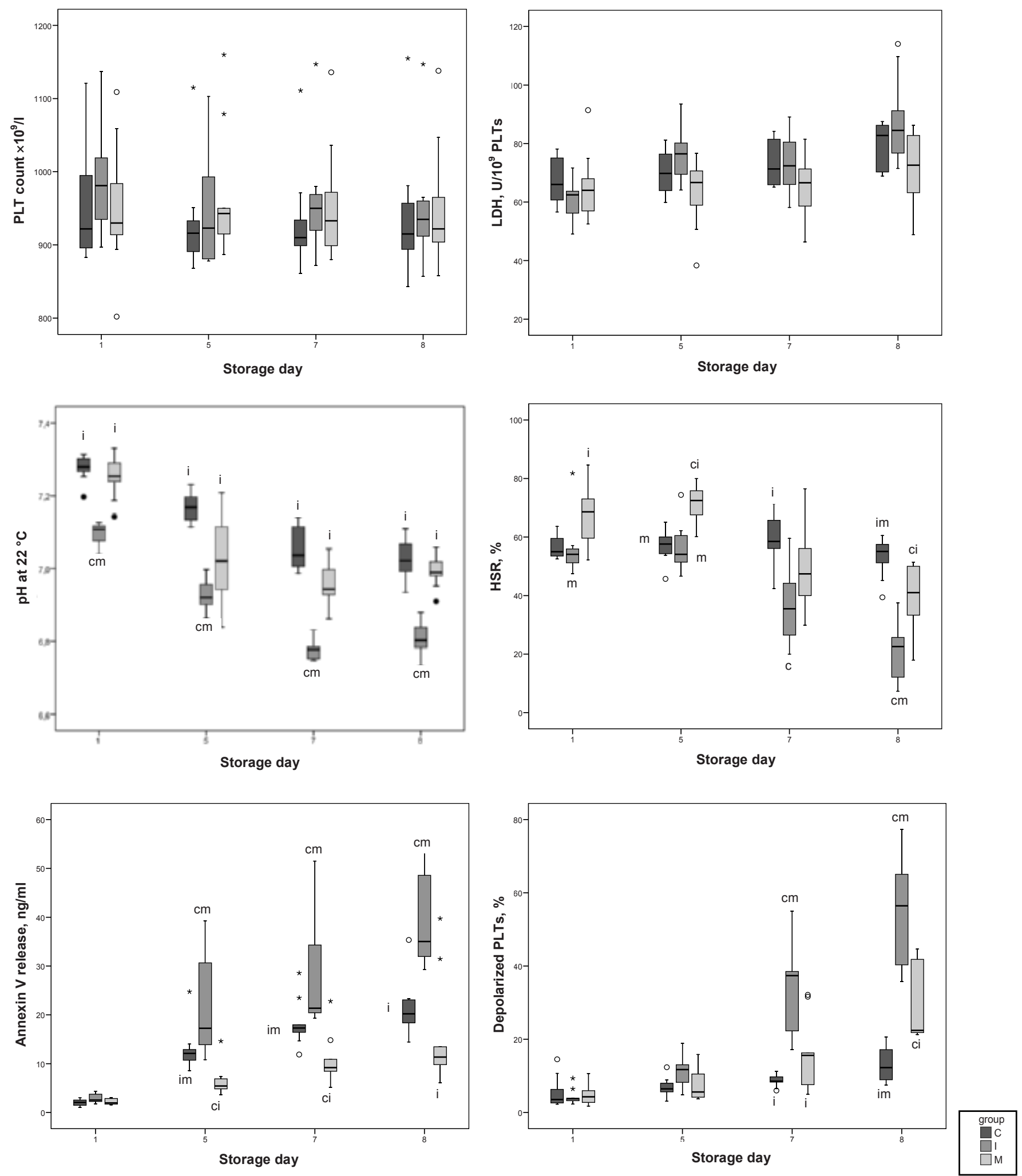

Fig. 1. Boxplot curves of cell quality parameters during 8 days of storage.

'Significant compared to C (untreated) units.

iSignificant compared to I (psoralen-UVA-treated) units.

${ }^{\mathrm{m}}$ Significant compared to M (riboflavin-UVB-treated) units. 
Table 1. Correlation coefficients (Spearman test) for bivariate correlation between annexin $\mathrm{V}$ release/JC-1 signal and $\mathrm{pH}, \mathrm{LDH}$ release and HSR
Fig. 2. Correlation (Spearman test) between annexin $\mathrm{V}$ release and JC-1 signal in PRT treated PLTs; $\mathrm{c}=$ correlation coefficient.

\begin{tabular}{|c|c|c|c|c|c|c|}
\hline & \multicolumn{3}{|c|}{ Annexin V } & \multicolumn{3}{|c|}{ JC-1 signal (\% depolarized PLTs) } \\
\hline & $\mathrm{C}$ & I & M & $\mathrm{C}$ & I & M \\
\hline $\mathrm{pH}$ value $\left(22^{\circ} \mathrm{C}\right)$ & -0.82 & -0.61 & -0.48 & -0.54 & -0.85 & -0.55 \\
\hline LDH release, U/ $10^{9}$ PLTs & 0.08 & 0.50 & 0.51 & 0.47 & 0.53 & 0.10 \\
\hline HSR, \% & -0.13 & -0.69 & -0.74 & -0.14 & -0.83 & -0.71 \\
\hline
\end{tabular}

$\mathrm{C}=$ untreated, $\mathrm{I}=$ psoralen-UVA-treated, $\mathrm{M}$ = riboflavin-UVB-treated units Italic letters indicate significance $(\mathrm{p}<0.05)$.

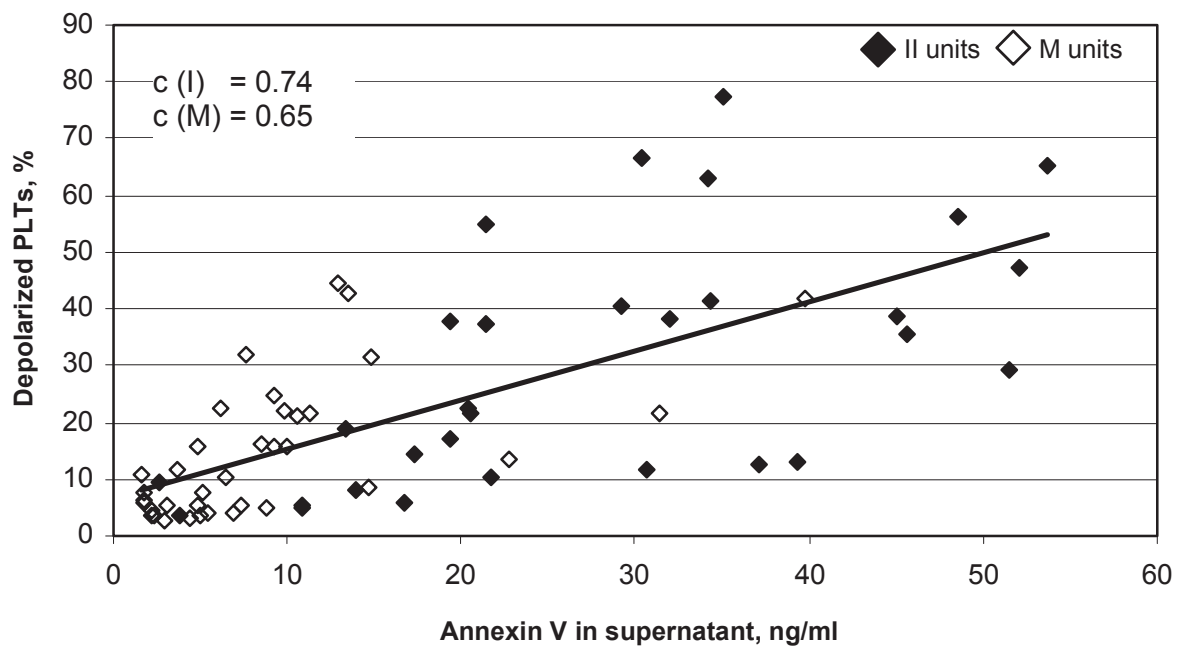

Statistical Analysis

Results obtained are expressed as median $\pm 95 \%$ confidence interval and analyzed by computer software (SPSS 15.0 for Windows, SPSS Software GmbH, Munich, Germany). Statistical analysis within a study group was conducted using the Friedman test, while the Kruskal-Wallis test was applied for the comparison of all three types of units. In case of significant differences $(\mathrm{p}<0.05)$, post-hoc paired comparisons were made with the Mann-Whitney U test. Here, according to Bonferroni, a p value of less than 0.017 was related to a significance level of $5 \%$. Correlation analysis was performed using the Spearman test for nonparametric correlations.

\section{Results}

The whole collection units yielded a median volume of $338 \mathrm{ml}$ (range 326-344 ml). Median PLT dose was $9.4 \times 10^{11}$ (range $\left.8.8-10.7 \times 10^{11}\right)$, corresponding to a median PLT concentration of $2,796 \times 10^{9} / 1$ (range, $2,620-3,138 \times 10^{9} / 1$ ). No serious adverse effects were observed in any of the apheresis procedures. All units were tested under sterile conditions after 16 days of incubation under aerobic and anaerobic conditions. Residual leukocytes and erythrocytes were well within the range of international guidelines [18]. Boxplot curves of cell quality parameters, including PLT count, $\mathrm{LDH}$ release, $\mathrm{pH}$ at $22{ }^{\circ} \mathrm{C}$, HSR, annexin $\mathrm{V}$ release, and JC- 1 signal from day 1 to day 8 of storage, are illustrated in figure 1 . Day 0 values obtained prior to splitting and PRT treatment were 1,075 $\pm 57 \times$
$10^{9} / 1$ for PLT count, $55.6 \pm 6.8 \mathrm{U} / 10^{9} \mathrm{PLT}$ for LDH in supernatant, $7.17 \pm 0.06$ for $\mathrm{pH}$ at $22{ }^{\circ} \mathrm{C}, 76.2 \pm 5.0 \%$ for HSR, 1.78 $\pm 0.33 \mathrm{ng} / \mathrm{ml}$ for annexin V in PC supernatant, and $4.5 \pm 5.7 \%$ for the percentage of depolarized cells. The correlation between released annexin $\mathrm{V}, \Delta \psi$ and conventional cell quality parameters examined is shown in table 1 . The correlation between annexin $\mathrm{V}$ release and $\Delta \psi$ is depicted in figure 2.

PLT counts and LDH release of all units changed only slightly during storage and revealed no significant differences among the study groups. During storage, annexin $\mathrm{V}$ release of all units increased steadily and was accompanied by a concomitant disruption of $\Delta \psi$. M units exhibited the lowest values for annexin $\mathrm{V}$ release, whereas I units had the highest, being significantly higher than those of $\mathrm{C}$ and $\mathrm{M}$ units by day 5 of storage. Regarding $\Delta \psi$, no significant differences were noted between $\mathrm{M}$ and $\mathrm{C}$ units during 7 days of storage, while I units demonstrated significantly higher $\Delta \psi$ disruption from the beginning of day 7. This was irrespective of the mode of $\Delta \psi$ expression (percentage of depolarized cells or mean fluorescence intensity (MFI) ratio (FL2/FL1) to also include partially depolarized cells) (fig. 3). On day 8, however, there were significant differences in $\Delta \psi$ between untreated controls and both types of PRT units, including M units. The analysis of more classical markers of the PLT storage lesion revealed no significant differences with respect to acidity between $\mathrm{C}$ and 
Fig. 3. MFI ratio FL2/FL1

The MFI ratio of I units as compared to untreated (C) and riboflavin-UVB-treated (M) units was significantly lower by day 7 of storage $(* \mathrm{p}<0.001)$

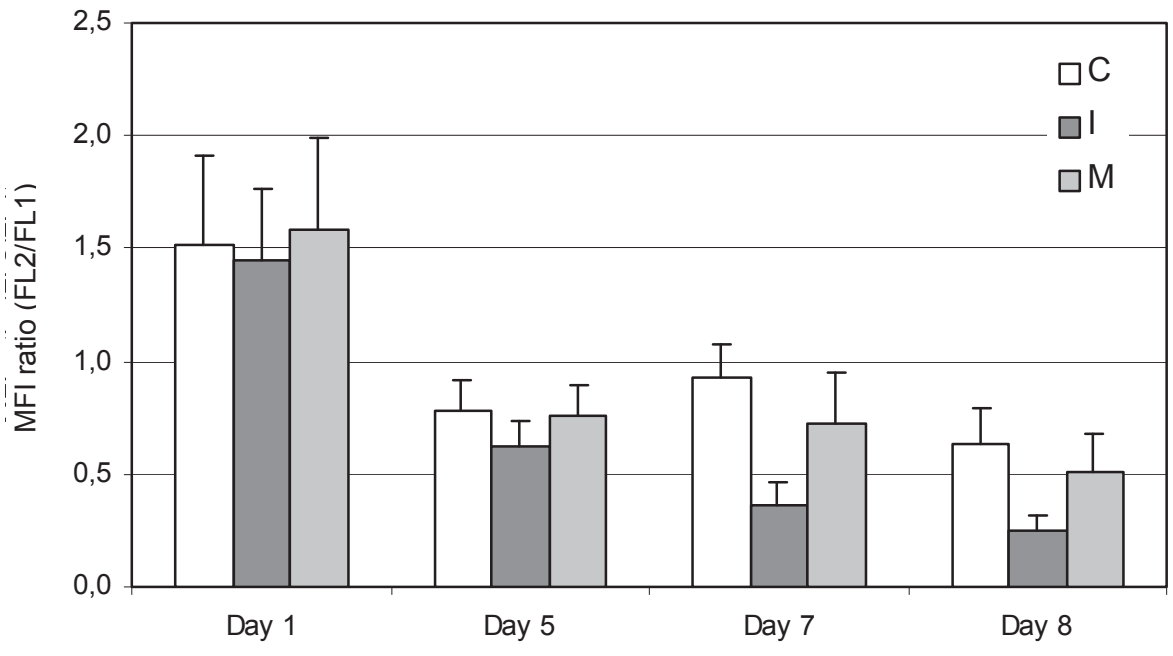

$\mathrm{M}$ units, whereas $\mathrm{pH}$ of I units was significantly lower already by day 1 of storage. Corresponding to the low annexin $\mathrm{V}$ release, HSR of M units exceeded that of the other units until day 5, but fell below $\mathrm{C}$ units by day 7 of storage. During the entire storage period, I units had the lowest values for HSR proving statistical significance versus $C$ units by day 7 of storage. After PRT treatment, annexin $\mathrm{V}$ release and $\Delta \psi$ were significantly correlated with HSR and $\mathrm{pH}$ value (table 1 ).

\section{Discussion}

PRT procedures may increase blood safety but also bear the potential to impair functionality and viability of the treated blood cells. In this study, we evaluated the effects of two different PRTs focusing on annexin $\mathrm{V}$ release and $\Delta \psi$ using apheresis-derived triple-dose PLTs stored in PAS for up to 8 days.

Because leukoreduced PCs with less than $1 \times 10^{6}$ white blood cells per unit were used, supernatant annexin $\mathrm{V}$ can be assumed to be entirely related to the release from PLTs. Given the steady increase of annexin $\mathrm{V}$ release and $\Delta \psi$ disruption in all study units, cellular alterations occurred during storage even in untreated PLTs that are reinforced by decreasing values of HSR and $\mathrm{pH}$. Interestingly, the correlation between annexin $\mathrm{V}$ release and $\Delta \psi$ with HSR was significantly more pronounced in PRT-treated compared to untreated units, suggesting a higher degree of cellular injury after PRT treatment.

$\Delta \psi$ disruption is associated with the apoptotic pathway [10] Thus, apart from increase in cellular injury, PRT treatment may enhance the apoptotic suicide machinery in stored PLT products. Comparing both PRTs, annexin V release and $\Delta \psi$ disruption were more pronounced after the psoralen-based PRT. With riboflavin as photosensitizer, annexin V release was even lower and $\Delta \psi$ remained comparable to untreated units during 7 days of storage which is in accordance with previous reports on $\Delta \psi$ [27]. The results obtained for $\Delta \psi$ in a former investigation on riboflavin-UVB treated PLTs [28] were 2 to 3 times higher than those obtained in the present study. Here, untreated and PRT-treated PLTs were resuspended in PAS instead of $100 \%$ of autologous plasma as performed in the previous investigation. Thus, a protective role for mitochondrial integrity could be supposed for PLT storage in PAS.

Our results of annexin $\mathrm{V}$ release and $\Delta \psi$ were underlined by the analysis of more conventional markers of the PLT storage lesion like $\mathrm{pH}$ and HSR. For $\mathrm{pH}$, lower values were observed with I units. However, $\mathrm{pH}$ of all units complied with international requirements ( $\mathrm{AABB}$ standards: $\mathrm{pH} \geq 6.2$ [29], Council of Europe recommendations: $\mathrm{pH} \geq 6.4$ [18]) throughout the entire storage period. As compared to untreated $\mathrm{C}$ units, the lower annexin $\mathrm{V}$ release of $\mathrm{M}$ units combined with higher HSRs, at least until storage day 5, could have resulted from differences in glucose metabolism, leading to better energy maintenance after PRT treatment with riboflavin-UVB. As reported previously, compared to untreated PLTs, riboflavin-UVB-treated PLTs exhibited an obviously up-regulated mitochondria-based respiration [25], which delivers profoundly more ATP than the anaerobic glycolytic pathway. On the other hand, PRT treatment with the psoralen-based technology appeared to impair oxidative phosphorylation [26]. As a consequence, I units mainly performed anaerobic glycolysis, resulting in less ATP generation and, as observed here, in lower HSRs and higher annexin $\mathrm{V}$ release.

We conclude that, due to the high correlation with HSR and $\mathrm{pH}$, the analysis of annexin $\mathrm{V}$ release and of the JC-1 signal (solely or combined) may indicate the degree of cellular injury and provides a sensitive and practical approach for quality monitoring of PCs, especially after PRT treatment. Results obtained demonstrated comparability between riboflavin-UVB-treated and untreated PLTs, but significantly 
lower values in psoralen-UVA-treated PLTs. It cannot completely be excluded that, apart from differences in PRT technology, differences in storage media (in contrast to InterSol, $\mathrm{SSP}+$ contains additional amounts of $\mathrm{K}^{+}$and $\mathrm{Mg}^{2+}$ ) could have contributed to differences in cell quality observed. Since differences to untreated controls became evident only later during storage, a storage period of maximally 7 days could be recommended for both kinds of PRT. The impact for PLT behavior in vivo, however, should be answered in the near future.

\section{Acknowledgement}

We would like to thank Astrid Kraemer and Silke Andresen (Cerus Europe B.V., Leusden, the Netherlands) as well as Nick Hovenga and Inge Reynaerts (CaridianBCT Biotechnologies, Lakewood, CO, USA) for their extensive collaboration during PRT treatment and data collection; furthermore Susanne Marschner and Raymond P. Goodrich (CaridianBCT Biotechnologies, Lakewood, CO, USA) for scientific support.

\section{Disclosure}

The authors declared no conflict of interest.

\section{References}

$>_{1}$ Knutson F, Alfonso R, Dupuis K, Mayaudon V, Lin L, Corash L, Högman CF: Photochemical inactivation of bacteria and HIV in buffy-coat derived platelet concentrates under conditions that preserve in vitro platelet function. Vox Sang 2000;78: 209-216.

2 Grass JA, Hei DJ, Metchette K, Cimino GD, Wiesehahn GP, Corash L, Lin L: Inactivation of leucocytes in platelet concentrates by photochemical treatment with psoralen plus UVA. Blood 1998; 91:2180-2188.

3 van Rhenen D, Gulliksson H, Cazenave JP, Pamphilon D, Ljungman P, Klüter H, Vermeij H, Kappers-Klunne M, de Greef G, Laforet M, Lioure B, Davis K, Marblie S, Mayaudon V, Flament J, Conlan M, Lin L, Metzel P, Buchholz D, Corash L: Transfusion of pooled buffy-coat platelet components prepared with photochemical pathogen inactivation treatment: the euroSPRITE trial. Blood 2003;101:2426-2433.

4 Goodrich L, Douglas I, Urioste M: Riboflavin photoinactivation procedure inactivates significant levels of bacteria and produces a culture negative product. Transfusion 2002;42:16S.

5 Goodrich L, Ghielli M, Hansen E, Woolum M, Gampp D, Goodrich R, Keil S: Riboflavin and UV light inactivate enveloped and non-enveloped viruses in platelet concentrates under conditions which maintain cell quality. Vox Sang 2002;83:111.

6 Ruane PH, Edrich R, Gampp D, Keil SD, Leonard RL, Goodrich RP: Photochemical inactivation of selected viruses and bacteria in platelet concentrates using riboflavin and light. Transfusion 2004; 44:877-885.

$\checkmark 7$ Verhoeven AJ, Verhaar R, Gouwerok EG, de Korte D: The mitochondrial membrane potential in human platelets: a sensitive parameter for platelet quality. Transfusion 2005;45:82-89.

$>8$ Krailadsiri P, Seghatchian J, Amiral J, Vissac AM, Contreras M: Annexin V, a new marker of platelet storage lesion: correlation with dMPV. Transfus Sci 1997;18:223-226.

$\checkmark$ Swairjo MA, Concha NO, Kaetzel MA, Dedman JR, Seaton BA: Ca2+-bridging mechanism and phospholipid head group recognition in the membrane-binding protein Annexin V. Nat Struct Biol 1995;2:968-947.
10 Heerde van WL, Robert-Offerman S, Dumont E, Hofstra L, Doevendans PA, Smits JFM, Daemen MJAP, Reutelingsperger C: Markers of apoptosis in cardiovascular tissues: focus on annexin V. Cardiovasc Res 2000;45:549-559.

11 Bevers EM, Comfurius P, Zwaal RFA: Changes in membrane phospholipid distribution during platelet activation. Biochem Biophys Acta 1983;736:57-66.

12 Williamson P, Bevers EM, Smeets EF: Continuous analysis of the mechanism of activated transbilayer lipid movement in platelets. Biochemistry 1995;34:10448-10455.

13 Bratton DL, Fadok VA, Richter DA, Richter DA, Kailey JM, Guthrie LA, Henson PM: Appearance of phosphatidylserine on apoptotic cells requires calcium-mediated non-specific flip-flop and is enhanced by loss of aminophospholipid translocase. J Biol Chem 1997;272:26159-26165.

14 Verhoeven B, Schlegel RA, Williamson P: Mechanism of phosphatidylserine exposure, a phagocyte recognition signal on apoptotic $\mathrm{T}$ lymphocytes. J Exp Med 1995;182:1597-1601.

15 Reutelingsperger CP, van Heerde WL: Annexin $\mathrm{V}$, the regulator of phosphatidyserine-catalyzed inflammation and coagulation during apoptosis. Cell Mol Life Sci 1997;53:527-532.

16 Romisch J, Schuler E, Bastian B, Bürger T, Dunkel FG, Schwinn A, Hartmann AA, Pâques EP: Annexin I to VI: quantitative determination in different human cell types and in plasma after myocardial infarction. Blood Coagul Fibrinol 1992;3:11-17.

17 Bundesärztekammer, Paul Ehrlich Institut: Richtlinien zur Gewinnung von Blut und Blutbestandteilen und zur Anwendung von Blutprodukten (Hämotherapie). Überarbeitete Fassung, Köln, Deutscher Ärzteverlag, 2005.

18 Council of Europe: Guide to the preparation, use and quality assurance of blood components, 14th ed. Strassbourg, Council of Europe Publishing, 2008.

19 Lin R, Alfonso R, Behrman B, Corten L, Damonte PB, Dikeman R, Dupuis K, Hei D, Lin CY, Londe HF, Metchette K, Phan T, Reames AA, Rheinschmidt M, Savoor A, Tessman J, Corash L: Photochemical treatment of platelet concentrates with a novel psoralen and UVA to enhance the safety of platelet transfusions. Infusionsther Transfusionsmed 1998;25:39-48.
20 Janetzko K, Klinger M, Mayaudon V., Lin L, Eichler $\mathrm{H}$, Klüter $\mathrm{H}$ : Storage characteristics of split double-dose platelet concentrates derived from apheresis and treated with amotosalen- $\mathrm{HCl}$ and UVA light for pathogen inactivation. Infus Ther Transfus Med 2002;29:193-198.

21 Picker SM, Speer R, Gathof BS: Functional characteristics of buffy-coat PLTs photochemically treated with amotosalen- $\mathrm{HCl}$ for pathogen inactivation. Transfusion 2004;44:320-329.

22 Li J, Lockerbie O, De Korte D, Rice J, McLean R, Goodrich RP: Evaluation of platelet mitochondria integrity after treatment with Mirasol pathogen reduction technology. Transfusion 2005;45:920-926.

23 Perez-Pujol S, Tonda R, Lozano M, Fuste B, Lopez-Vilchez I, Galan AM, Li J, Goodrich R, Escolar G: Effects of a new pathogen-reduction technology (Mirasol PRT) on functional aspects of platelet concentrates. Transfusion 2005;45:911-919.

24 Goodrich RP, Li J, Pieters H, Crookes R, Roodt J, Heyns AP: Correlation of in vitro platelet quality measurements with in vivo platelet viability in human subjects. Vox Sang 2006;90:279-285.

25 Picker SM, Steisel A, Gathof BS: Effects of MIRASOL PRT treatment on storage lesion development in plasma stored apheresis-derived platelets compared to untreated and irradiated units. Transfusion 2008;48:1685-1692.

26 Picker SM, Oustianskaia L, Schneider V, Gathof BS: Functional characteristics of apheresis-derived platelets treated with UV light combined with either amotosalen-HCl (S-59) or riboflavin (vitamin B2) for pathogen reduction. Vox Sang 2009;97:26-33.

27 Li J, Xia Y, Bertino AM, Coburn JP, Kuter DJ: The mechanism of apoptosis in human platelets during storage. Transfusion 2000;40:1320-1329.

28 Picker SM, Steisel A, Gathof BS: Cell integrity mitochondrial function after MIRASOL-PRT treatment for pathogen reduction of apheresis-derived platelets: results of a 3-arm in-vitro study. Transfus Apher Sci 2009;40:79-85.

29 Gorlin JB (ed): Standards for Blood Banks and Transfusion Services, 21th ed. Bethesda, American Association of Blood Banks, 2002. 